\title{
MAIN IMPACT OF TAX REFORM IN CHILE
}

\author{
Oscar Alfredo Rojas Carrasco \\ Postgraduate Department, Miguel de Cervantes \\ University \\ Santiago, Santiago, Chile \\ oscar.rojas@umcervantesecontinua.cl
}

\author{
Fernando Alejandro Herrera Ciudad \\ Postgraduate Department, Miguel de Cervantes \\ University \\ Santiago, Santiago, Chile \\ fernando.herrera@umcervantesecontinua.cl
}

\author{
Albino Enzon González González \\ Postgraduate Department, Miguel de Cervantes University \\ Santiago, Santiago, Chile \\ albino.gonzalez@profe.umcervantes.cl
}

Reception Date: 12/12/2018 - Approval Date: 04/25/2019

\section{ABSTRACT}

The purpose of this study is to analyze the tax reform and the tax change of the income tax, given that any reform to a tax system brings about distributional effects in society. Within the agenda of the newly assumed government, is tax reform as a measure to increase tax revenues, which aims to achieve, according to the draft law, four objectives: Increase the tax burden to finance, with permanent income, the ongoing expenses of the educational reform which is to be taken, other policies in the field of social protection and the current structural deficit in the fiscal accounts, Advance Equidad Tributaria, improving the distribution of income, introduce new and more efficient mechanisms of incentives for savings and investment, Ensure that it is paid as appropriate in accordance with the laws, progress in measures to reduce tax evasion and avoidance. The collection goal of all the measures of the Tax Reform will be $3 \%$ of GDP. This goal is decomposed into $2.5 \%$ of GDP from changes in the tax structure and $0.5 \%$ of GDP from measures that reduce evasion and avoidance, the estimated figure to be collected is US $\$ 8,200,000,000$.

KEY WORDS: Tax Reform, Law 600, Income Tax, Small Business.

\section{INTRODUCTION}

On April 1, 2014, the Chilean government sent a tax reform project to Congress, in order to replace the income tax system and to substantially modify that law and the tax code. On

\footnotetext{
"Visión de Futuro" Año 16, Volumen N²3 N², Julio - Diciembre 2019 - Pág. 21 - 36 URL de la Revista: http://visiondefuturo.fce.unam.edu.ar/index.php/visiondefuturo/index URL del Documento: http://visiondefuturo.fce.unam.edu.ar/index.php/visiondefuturo/issue/view/16 ISSN 1668 - 8708 - Versión en Línea E-mail: revistacientifica@fce.unam.edu.ar
} 
Wednesday May 6, 2014, it was approved by the Chamber of Deputies, still missing the Senate instance.

The above, under the need to raise more tribute to attend the petitions of the national movements popular, mainly, the student sector, which require a free education and quality, estimating that this new reform is Approximately 8.2 billion dollars (3.02\% of GDP).

To meet these social transformations and to have the necessary fiscal economic solvency and sustainable over time, this new tax reform will make important changes, such as the decrease of the social gap in education, health and protection Social, where we will analyze the main changes, considering as the one of greater weight what refers to the tax change of the income taxes, understanding that in, the current tax model (in force from 1984), The income tax of persons is integrated with that of the companies, where the owners are exempted from the complementary global tax, when the profits not withdrawn are invested in the business field, giving origin to the FUT (und for utilities taxable) ${ }^{1}$, where the companies, that They declare effective income in the first category, they record the history of the profits, which as means of investment have to meet the objective of promoting the development.

Every organized society requires a state that is capable of providing public goods compatible with the standard of living of its inhabitants and which can be sustained in time by means of taxation by its citizens. A good tax system should be sufficiently efficient in order to meet the growing demand for public services that the development of a society requires.

In Chile, the State has several mechanisms to collect the taxes, one of the most important is the tax that the persons pay for its revenues. This taxation is governed nowadays by the decree law Not 824 of December 31, 1984, which establishes the form as the domiciled or resident Chilean and foreign citizens in the country they must pay tax for its revenues, be this of any origin, be already that its earnings source is placed inside the country or out of.

With time, the Chilean society has achieved a greater development and welfare, allowing people to have a better standard of living. This has resulted in a higher public spending, which is funded in large part by the income tax. This has led to modify during these past 15 years several articles of Decree Law No. 824, so as to achieve a better and more efficient use of this law. But these changes have not been sufficiently effective to advance with

${ }^{1}$ FUT, Fund of profits taxable and corresponds to the utilities do not withdrawn from the company and therefore not included 1 in the tax base of the owners of the combanv.

\footnotetext{
"Visión de Futuro" Año 16, Volumen No 23 N², Julio - Diciembre 2019 - Pág. 21 - 36

URL de la Revista: http://visiondefuturo.fce.unam.edu.ar/index.php/visiondefuturo/index

URL del Documento: http://visiondefuturo.fce.unam.edu.ar/index.php/visiondefuturo/issue/view/16

ISSN 1668 - 8708 - Versión en Línea

E-mail: revistacientifica@fce.unam.edu.ar
} 
greater strength and efficiency in the supply of public goods that Chile needs for its development.

Since the year 2010, various agencies, both state and academic institutions for the study of public policies, have raised the need for profound changes to the tax structure Chilean, so as to be able to satisfy the increased demand for public goods that the country needs, in particular, education and health. This is why, last April, the executive branch of Chile sent a tax reform project to the National Congress for approval and subsequent application, which modifies the income tax system.

These changes to the income tax system are aimed at four basic objectives, namely:

1. Increase in the tax burden in order to achieve a higher revenues to finance public policies in education, health and shorten the structural deficit of the fiscal accounts.

2. To achieve equity taxation of income taxs, in particular, for micro and small entrepreneurs.

3. Introduce mechanisms that encourage savings and investment by companies, in particular, the smaller entities of the country.

4. Set explicit measures to decrease the levels of evasion and tax avoidance.

\section{DEVELOPMENT}

\section{Theoretical framework}

Focus on reforms to the tax system not only lays the foundations for a more equitable society, destroying more to those who have the most, but also gives the financial foundations for public policies in the long term, capable of improving the conditions of education, health, housing, etc. This not only enables you to build a more productive society and fair, but that also comes to respond to the heart of the social demands of Chile.

Since the tax to the revenue will be the main analysis inside the reform in this study, he will explain himself more in extensive to facilitate its comprehension, understanding that the taxes are contributions that the citizens are forced to pay for law, so that the State has sufficient resources to finance public needs. A type of tax that taxes the income that people, companies and other legal entities perceive, is the so-called income tax, which is basically classified as follows:

$>$ Supplementary Global tax, which taxes natural persons with domicile or residence in Chile.

The additional income tax, which taxes natural and legal persons, without domicile or residence in Chile.

\footnotetext{
"Visión de Futuro" Año 16, Volumen N² 23 N², Julio - Diciembre 2019 - Pág. 21 - 36

URL de la Revista: http://visiondefuturo.fce.unam.edu.ar/index.php/visiondefuturo/index

URL del Documento: http://visiondefuturo.fce.unam.edu.ar/index.php/visiondefuturo/issue/view/16

ISSN 1668 - 8708 - Versión en Línea

E-mail: revistacientifica@fce.unam.edu.ar
} 
$>$ First category tax, which affects natural and legal persons and is determined on the basis of effective rents and alleged incomes.

$>$ The Single Tax, that gravel to taxpayers that indicates the subparagraph 1 of art. 21 of the income tax law.

$>$ Single Tax of second category, which gravel to natural persons, dependent workers and pensioners.

For its part, taxpayers are classified to pay in the first and/or second category, depending on the type of income they earn, the first receive income from capital and companies; the latter perceive income from work, as is the case of dependent workers and independent. All taxpayers, whether in the first or second category of the Income Tax Act, have obligations for the mere fact of developing an economic activity affecting the payment of taxes.

Viewing the background context of this new project and with the purpose of the analysis of the tax reform and the change of taxation of the income tax, we placed in the current model and in the bases that underpinned their creation, comparing and evaluating the new proposed model.

\section{History of the Tributary Model}

According to Gonzalez (2014), expert tributarista, in Chat issued on 08 May 2014 at the University of Talca Headquarters Curico, the tax system in Chile until the year 1984, worked on the accrual basis, then there were two levels of taxation, a first level in the field of company and a second level in the field of the owners.

There existed a tax that was burdening the company, which is the same tax of the first category that we possess nowadays. In this time the valuation was corresponding to $10 \%$ and there existed a global complementary one very similar to the current one, with different stretches and different scales, and that its maximum valuation, only for effects of the present analysis, was corresponding to $45 \%$.

In both cases, what is taxd was the income earned, assuming that the income was $\$ 100$, the company should pay $\$ 10$, the owners $\$ 45$ and total tax revenues was, then, to $\$ 55$, this under the assumption that the income is affects the marginal rate highest in the G.C.

Year 1984, the country with financial problems, a banking in insolvency, difficulties in all economic activity, since many companies were broken, product also in part to these same policies, since it adopted a policy of openness to the world, which meant lower rates customs, doing more cheap the internment of imported products. Our industry never cared to have a good equipment of modern and efficient machinery, causing the inability to compete

\footnotetext{
"Visión de Futuro" Año 16, Volumen No 23 N², Julio - Diciembre 2019 - Pág. 21 - 36

URL de la Revista: http://visiondefuturo.fce.unam.edu.ar/index.php/visiondefuturo/index

URL del Documento: http://visiondefuturo.fce.unam.edu.ar/index.php/visiondefuturo/issue/view/16

ISSN 1668 - 8708 - Versión en Línea

E-mail: revistacientifica@fce.unam.edu.ar
} 
with the products that came from outside.

Summarizing the situation of that one then in the country, financial difficulties, insolvent banking, problems of productivity with companies that were possessing very ancient machineries and product of the opening to the world, the companies were not competitive. Low quality and high prices.

At the same time, there were professionals who were educated abroad, and the Chicago Boys appeared, who created the new tax model. One of the first questions made by them towards the current norm, went through the following question why tax the company?, if, ultimately, the company is nothing more than an organization that occurs in people and we can only conceive fruit of Our intelligence. Then, what should be taxd, are the owners, because when the company has utilities, is not this becomes more rich, but natural persons owning the company. Therefore, this first tax should not be considered.

On the other hand, there was a dilemma as to how society conceived. They wanted a society that would develop by delivering the widest possible faculties to the people and this meant, to subtract the scope from the state.

\section{Current Tax model}

This will arrive, finally, to raise a new model, which is now in force, which maintains the tax of first category and supplementary global, company and owner, but changing the basis, maintaining the accrual basis for the application of the tax to the company and by applying the tax to the owners at the time of the withdrawal or distribution of income. In addition, it incorporates a mechanism of integration between both taxs, establishing that the tax paid by firms will constitute a credit in favor of taxs on the owners

"So things, as the owner is taxd on the basis of a decision that he take, only taxd when you remove the income, profit pending withdrawal are those that give origin to the FUT" (Gonzalez, 2014). Then, the first category continued on an accrual basis, with the same rate of $10 \%$, for every 100 pesos of income, the state treasury received $\$ 10$ and as the basis of taxation that gravel to owner, It is on the basis of the decision that he take, discusses the two extreme situations: Do not remove anything: tax base $0 \%$, the tax $=\$ 0$ or removes the entire rent: If withdrew $\$ 100$, tax base $45 \%$, but the tax paid by the company is paid to what they would have to pay the owner. Then you must pay $\$ 35$.

Therefore, raising minimum potential with this model was $\$ 10$ and the maximum $\$ 45$. This new model reduced by $\$ 10$, the potential revenue maximum, compared to the previous model $(\$ 55)$.

\footnotetext{
"Visión de Futuro" Año 16, Volumen N²3 N², Julio - Diciembre 2019 - Pág. 21 - 36

URL de la Revista: http://visiondefuturo.fce.unam.edu.ar/index.php/visiondefuturo/index

URL del Documento: http://visiondefuturo.fce.unam.edu.ar/index.php/visiondefuturo/issue/view/16

ISSN 1668 - 8708 - Versión en Línea

E-mail: revistacientifica@fce.unam.edu.ar
} 


\section{Model tax proposed by the Reform}

With the model proposed in the Tax Reform, is born a new concept called income attributed, which differs from the concept earned, being wider than the latter, any time you understood as income some items in respect of which the taxpayer has no title or right. The company must pay a $25 \%$ tax, noting the current reform in project, a cut in interest rates, the maximum rate of the G.C. that today corresponds to a $40 \%$, would be reduced to $35 \%$, decreases the rate, but increases the base, as it now does not have the option in the scope of the G.C. not to remove.

All the income generated by the company is understood to be attributed to the owners in accordance with the percentages of participation that owns each one in it. As indicated, currently there are small businesses that are taxd on the basis of Article 14bis (to repeal) on the basis of withdrawal, i.e. if not removed there is no tax or of first category or supplementary global. Article 14bis operates under the current model, therefore, if not to withdraw the resources of its activity, the State presumed that the company was growing and reinvesting and as a mechanism of stimulus did not apply tax. Therefore, with the new reform, having to pay the tax on the basis of income attributed, businesses have fewer resources and must resort to credit to finance its operations, working capital and investment, which one can envisage will cause cost increases, lower production and probably increase in unemployment.

The 14bis, will be absorbed by the 14ter, being able companies opting for this alternative. Under this modality the way not to have tax base is to devote all the utilities, difference between income and expenditure, investment track purchase of goods, whether intended for the fixed assets or assets. Unfortunately, this modality of taxation would not be useful for services firms, since these are not realizable assets and do not require major investment in fixed assets.

Also, the tax reform considers regulatory changes to the current tax system Chilean, within which is the elimination of FUT (Fund for utilities taxable) and that corresponds to the utilities do not withdrawn from the company and therefore not included in the tax base of the owners of the company.

The grounds under which created the fut in the decade of the 80 , as a result of the economic situation in the country at that time, were the mechanism used to encourage investment to support the generation of employment and promotion to national economic growth. At the present time are no longer these conditions because the Chilean financial system account with a solidity similar to developed countries, and that in the recent global financial crisis this was demonstrated. However, not all companies have access to the

\footnotetext{
"Visión de Futuro" Año 16, Volumen N²3 N², Julio - Diciembre 2019 - Pág. 21 - 36

URL de la Revista: http://visiondefuturo.fce.unam.edu.ar/index.php/visiondefuturo/index

URL del Documento: http://visiondefuturo.fce.unam.edu.ar/index.php/visiondefuturo/issue/view/16

ISSN 1668 - 8708 - Versión en Línea

E-mail: revistacientifica@fce.unam.edu.ar
} 
financial system, so that the elimination of FUT (und for utilities taxable) can affect.

At the present time are no longer these conditions because the Chilean financial system account with a solidity similar to developed countries, and that in the recent global financial crisis this was demonstrated. However, not all companies have access to the financial system, so that the elimination of FUT can affect.

Within the changes brought in the reform is the elimination of FUT (Fund for utilities taxable) that said, in a simple way, are the utilities not withdrawn that generates a company, which at not be counted in the tax base, the partners do not pay tax on it. However, once that the utilities are removed, you must pay the tax supplementary global with the progressive rate that corresponds to the magnitude of the tax base, giving as credit the tax paid the company when they were generated profits. That is to say, if the person is taxd with an average rate of supplementary global $30 \%$, in response to which operates as a credit the tax paid by the company, currently with rate $20 \%$, the disbursement tributary to solve by the owner will only be of the order of $10 \%$.

With this elimination of FUT, the owners of the undertakings shall taxd on the total profits attributed by the company and not just on the profits withdrawn. Given that the FUT was born with the aim of increasing investment and to promote the economic development of the country, it is believed that this reform can go to the detriment of savings and reduce the investment of small and medium-sized enterprises.

With the aim of setting precedents, the FUT had its origin in a particular economic situation. The year 1984 Chilean companies had no ability to finance their investments. In the first place, the banking system was paralyzed after the crisis of the years 1982-1983. Secondly, the State of Chile was in arrears of their external debt, which made it impossible for enterprises to seek funding from the outside. Finally, our capital market was almost nonexistent in the year 1984. In this situation the companies only could finance their investments using their retained profits. In this context the FUT had economic sense.

The situation in Chile today is completely different. The Chilean banking system has a depth similar to many of the developed countries and has shown its strength in the recent global financial crisis. The capital market has had a great development in the last decades, allowing large enterprises could be financed with the issuing of bonds and equity. Lastly, companies can obtain financing abroad to reduced interest rates, thanks to low country risk that today presents Chile.

To a large extent, the FUT can be understood today as a transfer to the companies and, therefore, their owners. In this sense, an entrepreneur will invest up to where the benefit of the last weight $(\$)$ is equal to the opportunity cost of that weight. Given that it has a financial

\footnotetext{
"Visión de Futuro" Año 16, Volumen N² 23 N², Julio - Diciembre 2019 - Pág. 21 - 36

URL de la Revista: http://visiondefuturo.fce.unam.edu.ar/index.php/visiondefuturo/index

URL del Documento: http://visiondefuturo.fce.unam.edu.ar/index.php/visiondefuturo/issue/view/16

ISSN 1668 - 8708 - Versión en Línea

E-mail: revistacientifica@fce.unam.edu.ar
} 
system developed and open to the world, the opportunity cost of this last weight is determined by conditions in international financial markets. In spite of the fact that part of the investment is carried out with re-investment of profits, the last weight invested for the majority of companies is financed with external funds to the same. For this reason, in economic terms, the FUT affects mainly so infra-marginal investment, i.e. not the decision in the margin, which is what determines the last weight invested.

It is important to highlight that the elimination of the mechanism of the FUT will not affect small businesses, in accordance with the tributarista expert at the University of Talca, Gonzalez, in chat 2014. When considering the information of IBS for the year 2012, where $95 \%$ of the companies registered sales under $\$ 506$ million in the year, the changes introduced by the tax reform and that allow you to move to an accrual basis does not affect and even the smaller companies will see favored.

The new system on the basis of accrual is not, in essence, a novelty, since in the current income tax law there is already a similar system, which is expressly regulated in article 14 (b), to which 195,000 companies were accomodated in the year 2012.

To move to this new system of taxation of income on an accrual basis, you should consider the following rules in the time:

- Permanent Regime: that is regulated in detail in the amendments to the Law on Income Tax contained in article 1 of the draft, and that enters to govern in the marketing year 2017 to be applied, in property, during the tax year 2018.

- Transition until 31 December 2016: whose rules are contained in articles second and fourth transitory.

It will also examine a particular topic of the tax reform, which through Article $6^{\circ}$ of this reform, raises the repeal of Decree Law № 600 of 1974 The Foreign Investment Statute.

To perform a detailed analysis, first be presented the legal framework that governs the Decree Law $N^{\circ} 600$, detailing the legal personality that can possess the investor, the rights and obligations that owns both the State of Chile as the foreign investor to sign such a contract, the rights that have foreign investors, such as: Access to the formal exchange market, consignment of capital and profits, access to all economic sectors, resources of a claim of discrimination, election of the tax regime, indirect taxs and invariance specific tax on mining activity.

In addition describes the different forms of capital income that owns the foreign investor, this capital can come to our country with different forms of transfer, which may be: in foreign currency, physical assets, technology, credit associated with the investment, capitalization of

\footnotetext{
"Visión de Futuro" Año 16, Volumen Nº 23 N², Julio - Diciembre 2019 - Pág. 21 - 36

URL de la Revista: http://visiondefuturo.fce.unam.edu.ar/index.php/visiondefuturo/index

URL del Documento: http://visiondefuturo.fce.unam.edu.ar/index.php/visiondefuturo/issue/view/16

ISSN 1668 - 8708 - Versión en Línea

E-mail: revistacientifica@fce.unam.edu.ar
} 
credits and external debts and capitalization of profits.

Added to the previous thing, the economic indicators of foreign investment in our country will be presented which have been accepted to the Statute. For a better understanding, economic indicators will be given of the areas of productive activity that have received more foreign investment, as well as the countries that have made greater contribution to the economy.

To possess a technical profile of the tax reform, specifically in regard to the Decree Law $\mathrm{N}^{\circ} 600$, must be exposed, in summary form, the report of the Commission to modernise D.L. 600 , where renowned specialists and guests reflect their views with regard to the Statute. This commission was carried out within the discussion of the Law 20.469 introduces amendments to the taxation of mining activity, the year 2010.

Finally, and according to the background collected, is expressed a vision of the repeal of Decree Law N 600 The Foreign Investment Statute. The repeal of this Statute can be a big challenge for the country, due to the fact that foreign investment is not only picks in function of the economic characteristics and tax, but also by human factors, technological and sustainability of our resources.

Within the Tax Reform in Article 6 is to be repealed Decree Law No. 600, 1974 The Foreign Investment Statute. The derogation shall with effect from 1 January 2016, therefore, the Foreign Investment Committee (CIE), shall cease to hold new foreign investment contracts. The contracts already signed with the Committee, shall continue to be governed by existing legal standards applicable to contracts.

After the nationalization of copper in year 1971, during the government of President Salvador Allende G., there was the nationalization of foreign companies related with this mineral. Subsequently, with the coup and the formation of the military junta, you had to create a new mechanism for the transfer of capital into Chile, which would allow for the foreign investor to have security and incentive to carry out projects in the country. For these reasons, in the year 1974, creates the Decree Law $N^{\circ} 600$, where the foreign investor is benefited by a invariable tax, i.e. it is not affected by increases in the additional tax when you make a modification or tax reform.

The analysis of the importance of Decree Law $N^{\circ} 600$ begins to discuss at the Congress of Chile after the earthquake of 2010, on the occasion of the handling of the Law 20.469 "introduces amendments to the taxation of mining activity", where you create the commission modernization DL 600, formed by members of high-level national and where is invited to expose different experts related to foreign investment. The formation of this commission will be an excellent contribution to determine whether the Decree Law $N^{\circ} 600$ fulfilled his stage

\footnotetext{
"Visión de Futuro" Año 16, Volumen N²3 N², Julio - Diciembre 2019 - Pág. 21 - 36

URL de la Revista: http://visiondefuturo.fce.unam.edu.ar/index.php/visiondefuturo/index

URL del Documento: http://visiondefuturo.fce.unam.edu.ar/index.php/visiondefuturo/issue/view/16

ISSN 1668 - 8708 - Versión en Línea

E-mail: revistacientifica@fce.unam.edu.ar
} 
and may be reviewed, moreover, by the historical context of lower risk in which is located the country to foreign investors.

The Decree Law 600 (DL 600), begins its force in the year 1974, allowing a transfer of foreign capital into Chile. Through a voluntary scheme, foreign investors who enter capital, whether physical goods or other form of investment, requested to sign a contract of foreign investment with the State of Chile.

Foreign investors can benefit from the DL 600 according to the following ways:

a) Natural persons and foreign.

b) Foreign legal persons, which may be: legal persons in private law, legal persons of public law, foreign States and international organizations.

c) Natural persons and Chilean legal with residence and domicile abroad.

This statute provides for a contract between the State of Chile and the foreign investors, establishing rights and obligations between the two parties, this may not be modified or left without effect unilaterally by any of the parties that signed the contract. The rights granted by the Decree DL 600 are the following:

- I access to the formal exchange market; the foreign investor has guaranteed the access to the formal exchange market (banks and authorized exchange offices), so much to liquidate currencies of the capital contribution as also to acquire currencies to be sent for concept of capital or utility.

- Consignment of capital and profits; after a year since after the entry of foreign capital the investor may remit. Such consignment is exempt from any contribution, tax or levy, up to the amount of the investment materialized.

- Access to all economic sectors; investors may develop all kinds of economic activities in accordance with the legal provisions in force.

- Resource of a claim of discrimination; guarantees the foreign investor the application of the same laws and regulations that are applicable to local investors in the same productive activity

- Choice of tax regime; foreign investors are subject to an additional tax to the consignment of utilities and can choose to options which are the common system $35 \%$ as a tax to the first category, which operates as a credit in favor of the investor or the regime of invariable tax (Optional) $42 \%$ which is in a secure tributary in where is not varies the rate for 10 years. This latter scheme one can renounce once and will affect the tax regime common.

- Indirect Taxs; due to the invariance of the contracts in the period in which the investment was made, where the tax regime of the sales tax and service and tariff regime applicable to machinery and equipment which are not produced in the country. The goods

\footnotetext{
"Visión de Futuro" Año 16, Volumen No 23 N², Julio - Diciembre 2019 - Pág. 21 - 36

URL de la Revista: http://visiondefuturo.fce.unam.edu.ar/index.php/visiondefuturo/index

URL del Documento: http://visiondefuturo.fce.unam.edu.ar/index.php/visiondefuturo/issue/view/16

ISSN 1668 - 8708 - Versión en Línea

E-mail: revistacientifica@fce.unam.edu.ar
} 
that meet these conditions are exempted from payment of VAT.

- Invariance taxs specific to the mining activity; article 11 ter of the DL 600 indicates a regime of invariance of specific tax on mining activity for those investments exceeding US\$ 50 million. Investors should not be covered by the schemes of invariance laid down in Articles 7 and 11 bis of the DL 600, if they were must renounce them and the benefit of article 11 ter. Article 7 ter refers to the maintenance for a period of ten years of the rate of income tax to which they are subject.

Foreign capitals entering Chile may enter and be valued in the following ways:

a) Foreign currency of free convertibility.

b) Physical goods, in all forms or States.

c) Technology in its various forms when it is susceptible to be capitalized.

d) Credits that come associated with a foreign investment.

e) Capitalization of credits and external debts.

f) Capitalization of profits with the right to be transferred abroad.

On 6 October of the year 2010 and on the occasion of the handling of the Law 20.469 that introduces changes to the taxation of mining activity, an agreement was reached between the senators of the Finance Committee of the Senate and the ministers of finance and mining, aimed, among others, to the formation of a high-level commission to study the modernization of the Law Decree 600.

Not to mention that the care of the environment has been generating, gradually, greater awareness in people, global warming has been inserted as a topic of discussion at international level, the globalization of the world is something real, campaigns in their favor and the creation of systems self-sustaining is increasing the sensitivity to this issue.

The Government, through the executive, has proposed to the legislature, the day 01 April of this year, a bill to amend the tax system, with the aim of: to finance educational reforms, progress in tax equity, encourage savings and investment and reduce evasion and circumvention.

This bill makes reference to the topic of the environment by establishing taxs applied to issuers of polluting gases from fixed sources and vehicles that use diesel and fuel.

This project does not set concrete measures with regard to tax incentives for the creation of projects aimed at the generation of energy by non-conventional systems and renewable energy, with the aim of reducing, indeed, pollutant emissions and seize, efficiently, the unlimited resources coming from large natural sources such as: the sea, the wind, the sun and the geothermal energy.

\footnotetext{
“Visión de Futuro" Año 16, Volumen N² 23 N², Julio - Diciembre 2019 - Pág. 21 - 36

URL de la Revista: http://visiondefuturo.fce.unam.edu.ar/index.php/visiondefuturo/index

URL del Documento: http://visiondefuturo.fce.unam.edu.ar/index.php/visiondefuturo/issue/view/16

ISSN 1668 - 8708 - Versión en Línea

E-mail: revistacientifica@fce.unam.edu.ar
} 
Similarly, presents no proposals to encourage the preservation of the natural resources existing in the territory of Chile. Take a special interest those resources that are renewable and that of being exploited, in a rational manner, are enduring in time. It is essential to establish a strong policy of the Government that, through the tool of the taxs, generate all the possible conditions for the actual protection of the environment.

In this sense, the tax reform seeks, as its fundamental objective, to finance on a permanent basis the educational reform, to move forward with tax equity, the incorporation of mechanisms of incentives to savings in investment and, finally, progress in effective laws to reduce tax evasion and avoidance.

\section{Analysis and results}

Below is a summary of the main changes or differences and their impacts, the system proposed by the reform versus the current system.

Table No.1. Major amendments to the reform of the Income Tax

\begin{tabular}{|c|c|c|}
\hline № & Item modified & Main Modifications \\
\hline 1 & $\begin{array}{l}\text { Increase in the } \\
\text { tax rate of First } \\
\text { Category: }\end{array}$ & $\begin{array}{l}\text { Is gradually increased, from } 20 \% \text { to } 25 \% \text {, the rate of tax of first } \\
\text { category }(21 \% \text { in } 2014,22.5 \text { per cent in } 2015,24 \text { per cent in } 2016 \text {, to } \\
\text { reach } 25 \% \text { in } 2017) \text {. }\end{array}$ \\
\hline & Taxation on & $\begin{array}{l}\text { With the taxation on accrual basis, the FUT is eliminated definitively } \\
\text { from the commercial year } 2017 \text {. }\end{array}$ \\
\hline 2 & $\begin{array}{l}\text { accrual } \\
\text { basis/elimination of } \\
\text { the Taxable Profit } \\
\text { Fund (FUT): }\end{array}$ & $\begin{array}{l}\text { It also adds a withholding tax equivalent to } 10 \text { per cent in society } \\
\text { source that generates the utilities attributable; and in the event that rents } \\
\text { are attributed to a non-resident taxpayer or domiciled in Chile, the } \\
\text { retention shall be equal to the difference between } 35 \text { per cent and the } \\
\text { tax rate of first category. }\end{array}$ \\
\hline 3 & Personal taxes & $\begin{array}{l}\text { From the year } 2017 \text {, the maximum rate of personal taxation, that is, tax } \\
\text { of second category and Global Tax complementary, is reduced from the } \\
\text { current } 40 \% \text { to } 35 \% \text {. }\end{array}$ \\
\hline \multirow{5}{*}{4} & \multirow{5}{*}{$\begin{array}{l}\text { Taxation of Capital } \\
\text { gains }\end{array}$} & i) Any capital gain will be taxd with income tax. \\
\hline & & $\begin{array}{l}\text { ii) Removes the exemption of capital gains from the disposition of real } \\
\text { estate. }\end{array}$ \\
\hline & & $\begin{array}{l}\text { iii) In relation to the cost of the actions and social rights, is recognized } \\
\text { as part of this, retained earnings and attributed in society between the } \\
\text { date of acquisition and the date of disposal of shares or social rights. }\end{array}$ \\
\hline & & $\begin{array}{l}\text { iv) In the case of acquisition of shares or rights financed with debt, the } \\
\text { interests shall not be deductible from the taxable base of first category, } \\
\text { but will increase the cost of acquisition of these rights or actions. }\end{array}$ \\
\hline & & $\begin{array}{l}\text { V) Modifies the taxation of capital gains which currently distinguishes } \\
\text { between gains regular and non-regular. Sets a differentiated treatment } \\
\text { according to the time of possession of these goods (less than or equal } \\
\text { to one year; and more than one year). }\end{array}$ \\
\hline
\end{tabular}

\footnotetext{
"Visión de Futuro" Año 16, Volumen No 23 N², Julio - Diciembre 2019 - Pág. 21 - 36

URL de la Revista: http://visiondefuturo.fce.unam.edu.ar/index.php/visiondefuturo/index

URL del Documento: http://visiondefuturo.fce.unam.edu.ar/index.php/visiondefuturo/issue/view/16

ISSN 1668 - 8708 - Versión en Línea

E-mail: revistacientifica@fce.unam.edu.ar
} 


\begin{tabular}{|c|c|c|}
\hline 5 & Taxation of funds & $\begin{array}{l}\text { The law is changed only of funds (Law 20.712), recently adopted by } \\
\text { the Congress, by changing the tax regime and taxing to the holders of } \\
\text { shares of funds on an accrual basis or allocated. The administrating } \\
\text { companies shall retain, declare and pay a } 10 \% \text { on the total value of the } \\
\text { result tributary obtained by the Fund. In relation to the Private } \\
\text { Investment Funds, the administrator must practice a withholding of } 35 \% \\
\text { of all the utility earned the fund. }\end{array}$ \\
\hline \multirow{4}{*}{6} & \multirow{4}{*}{$\begin{array}{l}\text { International } \\
\text { Rules }\end{array}$} & $\begin{array}{l}\text { i) Rules CFCS (Controlled Foreign Corporation): Sets a standard that } \\
\text { prevents to defer the payment of taxs on passive incomes from foreign } \\
\text { sources. }\end{array}$ \\
\hline & & ii) Residence: incorporates the concept of beneficial owner. \\
\hline & & $\begin{array}{l}\text { iii) Deduction of expenses incurred abroad with related parties: only to } \\
\text { the extent that the expenditure has been paid and have been retained } \\
\text { the additional tax to which you can find affections. }\end{array}$ \\
\hline & & $\begin{array}{l}\text { iv) Standards of over-indebtedness: New Standard for the calculation } \\
\text { of over-indebtedness that affects the interests and any other surcharge } \\
\text { or financial expenditure, which is paid to related entities from outside. }\end{array}$ \\
\hline 7 & $\begin{array}{l}\quad \text { Improvements } \\
\text { to the mechanisms } \\
\text { of } \\
\text { Depreciation }\end{array}$ & $\begin{array}{l}\text { It introduces a mechanism of depreciation snapshot available for } \\
\text { micro and small enterprises. The medium sized companies can access } \\
\text { the Mechanism of depreciation special. }\end{array}$ \\
\hline \multirow{4}{*}{8} & \multirow{4}{*}{$\begin{array}{l}\text { Special rules for } \\
\text { small businesses }\end{array}$} & $\begin{array}{l}\text { 1) Extending the benefits of article } 14 \text { ter: may access this regime, all } \\
\text { individual companies and legal persons whose annual sales do not } \\
\text { exceed } 25,000 \text { UF. Deletes the simplified regimens contained in articles } \\
14 \text { bis and } 14 \text { quater of the Law on Income Tax. }\end{array}$ \\
\hline & & $\begin{array}{l}\text { ii) Special rules on provisional payments Monthly (PPM): companies } \\
\text { under the article } 14 \text { ter, will be subject to lower rates in respect of its } \\
\text { PPM. It also establishes a rebate transitory of } 15 \% \text { in the payment of the } \\
\text { PPM for medium and small businesses during the first } 12 \text { months from } \\
\text { the entry into force of the reform. }\end{array}$ \\
\hline & & $\begin{array}{l}\text { iii) Change in the subject of the payment of VAT: Large companies } \\
\text { (sales of over 100,000 UF) may assume as subjects paying VAT. }\end{array}$ \\
\hline & & $\begin{array}{l}\text { iv) Credit for the purchase of fixed assets: Is increased from } 4 \text { per } \\
\text { cent to } 6 \text { per cent (of the amount invested), the credit for investment in } \\
\text { fixed assets, in respect of micro, small and medium-sized enterprises. } \\
\text { The latter with the exception that applies to them a linear formula on the } \\
\text { basis of which, the benefit decreases while they are approaching the } \\
\text { size of large company. }\end{array}$ \\
\hline
\end{tabular}

Source: Own Elaboration

\section{Other taxs modified by the Reform}

Green taxs, are created green taxs levied on certain goods that are not friendly to the environment. So, sets a tax on emissions from fixed sources that gravel the emission of certain pollutants and an additional tax on the import of light vehicles more pollutants that use diesel.

\footnotetext{
"Visión de Futuro" Año 16, Volumen N² 23 N², Julio - Diciembre 2019 - Pág. 21 - 36

URL de la Revista: http://visiondefuturo.fce.unam.edu.ar/index.php/visiondefuturo/index

URL del Documento: http://visiondefuturo.fce.unam.edu.ar/index.php/visiondefuturo/issue/view/16

ISSN 1668 - 8708 - Versión en Línea

E-mail: revistacientifica@fce.unam.edu.ar
} 
Corrective tax increases the specific tax on alcoholic beverages, non-alcoholic beverages that present high content of sugars and the energizing or hypertonic.

Real Estate, intends to levy VAT the regular buy real estate new or used. Deletes the provision of article 21 of DL 9101975 to housing with a value greater than the 2,000 UF and restricts the maximum amount from 225 UF 100 UF.

Tax of Timbres and Stamps, increases the maximum rate of tax of Timbres and Stamps from the current $0.4 \%$ to $0.8 \%$.

\section{Repeal of Decree Law No. 600 (Foreign Investment Statute)}

The reform proposed to repeal the DL No 600 from 1 January 2016, for new investment projects. However, holders of investment contracts already signed with the Foreign Investment Committee, shall continue to be governed by existing legal standards applicable to their contracts.

\section{Rules to combat the circumvention and tax evasion}

Incorporate the following rules to combat the avoidance and tax evasion:

a. General Anti-Circumvention rule that allows the SII to reject the tax advantages obtained through elusive, abusive or simulated planning and to penalize taxpayers and tax consultants who have participated in their design.

b. Establishes rules that empower the SII to access the information necessary to fulfil its supervisory mission.

c. Rules that allow the SII to access the information of purchases paid by electronic means (credit and debit cards).

\section{CONCLUSION}

To think that the taxs per se have an influence on the equality would be a great paradox, given that global experience shows that if you increase the taxs to the richest people, they are globalized, and therefore have the possibility of changing its wealth and income to countries with lower taxs, then you might think that if the apply high taxs in a sustained way, the rich will disappear, even if it confiscates the total wealth of the rich is not going to make the poor more rich, by which taxs as such are not an instrument against inequality, rather it is a myth of the nineteenth century, that through the taxs can bring equity, if not more well, they are only a means distributive to generate employment and improve education, which

\footnotetext{
"Visión de Futuro" Año 16, Volumen No 23 N², Julio - Diciembre 2019 - Pág. 21 - 36

URL de la Revista: http://visiondefuturo.fce.unam.edu.ar/index.php/visiondefuturo/index

URL del Documento: http://visiondefuturo.fce.unam.edu.ar/index.php/visiondefuturo/issue/view/16

ISSN 1668 - 8708 - Versión en Línea

E-mail: revistacientifica@fce.unam.edu.ar
} 
themselves are elements that generate equity.

That is why the reform transcendental in Chile would be the reform of the education, financed by the tax reform, but not the entire education, if not more good, public education basic, given that the economist and philosopher French Guy Sorman (2015) ensures, that in Chile the half of the population is not really sharing of social and economic progress since 30 years ago, By that these persons come from a past poor, usually, provinces far away that they cannot benefit from the progress, because they do not have access to a decent basic education, are mired in mediocre and poor public schools, where the priority should be to give them a proper education, whether public or private subsidized. So is incorporated to this population that remains poor by the precarious education.

The current reform, due to the length of their interpretation, given that each modification, necessarily, refers to the original article of the act to be amended and the unfamiliarity with technical, not many display of points of importance of the reform and that, to personal assessment contradict with the want to make progress in tax equity by law and to improve the distribution of income.

There are reforms aimed to demolish the few benefits that the State still delivery to the middle class, building a deep trench where the small employer must try to quit with an aid harmful of the financial system by the high rates of interest to you access, inadequate support given that never financed $100 \%$ of their financial requirements new, by the credit risk that this implies and bureaucratic, Since there is no history of the performance of small firms under this new scenario tax, by which will lengthen the period of risk analysis of credit necessary for the adoption of new funds bancarizables.

Nothing is said of the impact that the reform will have on the contributors of Pension Funds, which is estimated at a low of 6 per cent of their pensions in the future. This substantial decline will result from that pension funds may not transfer its affiliates a tax credit of first category that affects stock dividends which they perceive and that with the ongoing reform would lead to a real burden of $35 \%$.

Therefore, this reform will attempt directly against the contributors of lower income, even while they were exempted from the Tax Supplementary Global or affections to an effective rate of $2 \%$, will end up supporting a load of $35 \%$ for obtaining these dividends.

More than 70 per cent of workers and contributors of low income must bear the tax burden of $35 \%$ by the benefits that their pension funds obtained, the same load as the Law of Income envisaged for the large international firms and persons of higher income in the country.

To greater effort in trying to see as this measure allows us to make progress on tax

\footnotetext{
"Visión de Futuro" Año 16, Volumen N² 23 N², Julio - Diciembre 2019 - Pág. 21 - 36

URL de la Revista: http://visiondefuturo.fce.unam.edu.ar/index.php/visiondefuturo/index

URL del Documento: http://visiondefuturo.fce.unam.edu.ar/index.php/visiondefuturo/issue/view/16

ISSN 1668 - 8708 - Versión en Línea

E-mail: revistacientifica@fce.unam.edu.ar
} 
equity and improve the distribution of income, the more it becomes clear that this reform brings changes that seriously affect our middle class.

Thus we see the repeal of article 57 bis that benefits and encourages saving, the twofold increase in the Tax of rings that affects consumer and mortgage loan, the elimination of the benefit that against the VAT are real estate with a value greater than the 2,000 UF, the proposal of affect with VAT the sale of immovable property of all kinds, Including those destined for housing, the affectation with income tax the gain that a natural person may have on the sale of a property that has been acquired with the encouragement of investment for their old age, the creation of a new tax that will affect all diesel vehicle particular, etc.

As mentioned at the beginning of this report, we believe that any changes are needed to reduce the gap of inequality of income and opportunities rooted historically in our country, remain positive changes or reforms that enhance the intellectual capabilities and Professionals of each citizen to exercise its right to take and overcome daily, Being for it as a fundamental basis a free education, quality and equitable opportunity, not influenced by external entities.

As indicated by the Senator Zaldívar (2014), in an interview given to the newspaper El Mercurio, on Wednesday 21 May 2014: "The heart of the tax reform is susceptible of improvements", stating that in the upper house the central points of the draft, as the rise of taxs to the companies and the elimination of FUT, yes will be analyzed.

We can therefore conclude that the tax reform is necessary on the basis of the historical situation of our country, for the sake of a sought equal citizenship, but it is necessary to improve various aspects of this project, so that it does not become a reform ideal in its structure written, but a failure when applying and carried out, transforming itself into a new TranSantiago.

\section{REFERENCES}

Please refer to articles in Spanish Bibliography.

\section{BIBLIOGRAPHCIAL ABSTRACT}

Please refer to articles Spanish Biographical abstract.

\footnotetext{
"Visión de Futuro" Año 16, Volumen No 23 N², Julio - Diciembre 2019 - Pág. 21 - 36

URL de la Revista: http://visiondefuturo.fce.unam.edu.ar/index.php/visiondefuturo/index

URL del Documento: http://visiondefuturo.fce.unam.edu.ar/index.php/visiondefuturo/issue/view/16

ISSN 1668 - 8708 - Versión en Línea

E-mail: revistacientifica@fce.unam.edu.ar
} 